Original Paper

\title{
Peningkatan Kemampuan Siswa dalam Mengembangkan Argumen Bernegosiasi melalui Pembuatan Dialog Film Pendek
}

\author{
Ilhamuddin Aminullah ${ }^{*}$ \\ ${ }^{1}$ Sekolah Menegah Atas Negeri 1 Mataram, Kota Mataram, Nusa Tenggara Barat, Indonesia
}

DOI: https://doi.org/10.29303/jcar.v3i2.895

${ }^{*}$ Corresponding Author:

Ilhamuddin Aminullah, Sekolah

Menegah Atas Negeri 1 Mataram,

Kota Mataram, Nusa Tenggara

Barat, Indonesia.

Email:

ilhamuddinaminullah@gmail.com

\begin{abstract}
Abstrak: Tujuan penelitian ini adalah untuk menguraikan upaya meningkatkan kemampuan siswa kelas X Mipa-2 SMAN 1 Mataram tahun pelajaran 2020/2021 dalam mengembangkan argumen teks negosiasi melalui dialog film pendek. Penelitian dilaksanakan dalam 2 siklus. Setiap siklus meliputi tahap (1) perencanaan, (2) tindakan, (3) observasi, dan (4) refleksi. Data dikumpulkan dengan metode observasi, tes, catatan lapangan, dan dokumenter. Data yang diperoleh melalui observasi dianalisis untuk melihat ketercapaian indikator tindakan, sedangkan data yang diperoleh melalui tes dianalisis untuk melihat ketercapaian indikator kompetensi mengembangkan argumen teks negosiasi. Analisis data dilakukan secara deskriptif. Hasil penelitian menunjukkan bahwa terjadi peningkatkan kemampuan mengembangkan argumen dalam teks negosiasi siswa kelas X Mipa-2 SMAN 1 Mataram tahun pelajaran 2020/2021 melalui dialog film pendek. Hal terebut dibuktikan dengan adanya peningkatan nilai rata-rata siswa secara klasikal yaitu dari 75,05 pada prasiklus menjadi 78,86 (siklus I), dan 81,71 (siklus II), dan peningkatan ketuntasan belajar secara klasikal yaitu dari $57,14 \%$ pada prasiklus menjadi $74,29 \%$ (siklus I), dan $88,57 \%$ (siklus II).
\end{abstract}

Kata kunci: argument; teks negosiasi; dialog; film pendek

\section{Pendahuluan}

Pembelajaran mata pelajaran Bahasa Indonesia dimaksudkan untuk membina dan mengembangkan kepercayaan diri siswa sebagai komunikator, pemikir, dan menjadi warga negara yang melek literasi dan informasi. Pembelajaran Bahasa Indonesia bertujuan membina dan mengembangkan pengetahuan, keterampilan, dan sikap komunikasi yang diperlukan siswa dalam menempuh pendidikan, hidup di lingkungan sosial, dan berkecakapan dalam dunia kerja.

Materi pelajaran teks negosisi yang diprogramkan di kelas X SMA, diarahkan untuk menunjang pencapaian maksud dan tujuan pembelajaran Bahasa Indonesia di atas. Melalui pembelajaran teks negosiasi, siswa diharapkan memiliki kemampuan berkomunikasi khususnya komunikasi yang mengarah pada ketercapaian kesepakatan dengan pihak lain. Hal ini menjadi lebih penting jika dikaitkan dengan kehidupan global yang penuh persaingan dalam berbagai hal. Dalam kondisi persaingan itu, sangat dibutuhkan kemampuan menegosiasikan berbagai perbedaan dalam rangka mencapai kesepakatan yang menguntungkan pihak-pihak yang terlibat dalam negosiasi. Siswa dipersiapkan agar memiliki kompetensi dalam menegosiasikan 
berbagai hal yang berkaitan dengan kehidupannya di masa yang akan datang.

Pengalaman penulis/peneliti dalam pembelajaran teks negosiasi khususnya di SMAN 1 Mataram menunjukkan beberapa kesulitan siswa dalam memahami materi, baik yang berkaitan dengan dengan konten teks negosiasi maupun aspek kebahasaan. Khusus di X Mipa-2 SMAN 1 Mataram tahun pelajaran 2020/2021, kesulitan atau kelemahan utama yang teridentifikasi adalah siswa belum mampu mengembangkan argumen. Sebagian siswa mengeluhkan hal yang berkaitan dengan pengembangan argument dalam melakukan negosiasi. Padahal dalam struktur teks negosiasi, bagian argumen merupakan unsur pokok. Kesepakatan (sebagai simpulan negosiasi) yang dicapai dalam negosiasi amat bergantung pada argumen-argumen yang dikemukakan. Argumen yang kuat akan menguatkan posisi negosiator dalam bernegosiasi. Begitu seseorang sampai pada kesimpulan yang didukung dengan baik oleh alasan-alasan, argumen juga adalah cara untuk menjelaskan dan mempertahankannya (Weston, 2007). Keberhasilan negosiasi memerlukan adanya penyampaian argumen yang kuat sehingga mampu memengaruhi pihak lain dalam mencapai kesepakatan (Guntur, 2010). Siswa kelas X Mipa-2 SMAN 1 Mataram tahun pelajaran 2020/2021 baru mampu menyampaikan argumen-argumen sederhana dan singkat yang menyebabkan mereka berada dalam posisi yang lebih lemah dalam negosiasi. Kalaupun siswa dalam posisi menguntungkan dalam kesepakatan yang dicapai, ketidakmampuan mengembangkan argumen menyebabkan siswa belum memperoleh keuntungan maksimal dalam kesepakatan tersebut.

Kelemahan siswa mengembangkan argumen dalam teks negosiasi memerlukan alternatif pemecahan. Salah satu alternatif yang dicoba untuk diterapkan adalah dengan menugaskan siswa menyusun dialog yang akan disampaikan dalam film pendek yang akan mereka buat. Dialog tersebut difokuskan pada pengembangan argumen negosiasi. Dalam hal ini, siswa secara berkelompok akan ditugaskan membuat film pendek berisi negosiasi. Dialog-dialog dalam film pendek tersebut ditekankan pada kekuatan argumen. Penilaian utama akan ditekankan pada argumen siswa dalam bernegosiasi. Dalam penelitian ini, film pendek hanya berfungsi sebagai media pendukung untuk menarik minat siswa dalam belajar. Penggunaan film sebagai sarana pembelajaran teks negosiasi memang dimungkinkan karena menurut Arsyad (2016) film termasuk media yang digunakan untuk pembelajaran di sekolah. Sabri (dalam Musfiqon, 2012) mengemukakan bahwa film memiliki keuntungankeuntungan sebagai media pembelajaran.

$$
\text { Pelaksanaan pembelajaran teks }
$$

negosiasi dengan menyusun dialog film pendek atau pemanfaatan media film sebagai sarana melatih kompetensi bernegosiasi diasumsikan akan dapat memecahkan kelemahan siswa dalam pembelajaran teks negosiasi khususnya dalam mengembangkan argumen. Alternatif pemecahan yang dilakukan dengan melaksanakan pembelajaran memanfaatkan media film didasarkan pada beberapa hal, yakni (1) siswa menyukai dan terbiasa menggunakan fasilitas teknologi dan informasi dengan berbagai aplikasi sesuai dengan perkembangan terkini seperti kamera, video, dan sebagainya, (2) siswa sering melakukan dialog melalui media teknologi informasi, (3) pemanfaatan kesukaan siswa pada produk IT untuk menunjang pembelajaran juga didasarkan pada asumsi bahwa hal itu akan membuat pembelajaran lebih bervariasi dan menyenangkan yang akan meningkatkan kompetensi siswa pada materi yang sedang dipelajari tersebut, (4) pemanfaatan produk IT akan melibatkan siswa secara langsung dalam pembelajaran, dan (5) siswa banyak yang memiliki hobi membuat film-film pendek dengan aplikasi yang ada pada HP mereka. 
Beberapa hasil penelitian sebelumnya memperkuat alasan peneliti memanfaatkan media film dalam mendukung pembelajaran dan penelitian ini. Penelitian tentang pengaruh media film untuk meningkatkan hasil belajar siswa telah dilakukan oleh Jefrilianto et al., (2019) yang menggunakan jenis penelitian eksperimen dengan metode diskriptif kualitatif tersebut menyimpulkan bahwa penerapan pembelajaran berbasis film memberikan pengaruh yang signifikan terhadap hasil belajar siswa. Penelitian lain dilakukan oleh Maharani et al., (2019) yang meneliti efektivitas penggunaan media film bertema pendidikan dalam meningkatkan kemampuan berpikir kritis siswa SMA Al Muslim Tambun, Bekasi. Penelitian dengan jenis eksperimen semu dengan teknik simple random sampling tersebut menyimpulkan bahwa terdapat pengaruh yang signifikan penggunaan media film bertema pendidikan dalam layanan bimbingan klasikal terhadap terhadap kemampuan berpikir kritis siswa.

\section{Metode}

Pemecahan masalah dilakukan dengan penelitian tindakan kelas, yaitu seperti yang dikemukakan Wardhani (2007) kesulitan siswa dalam mengembangkan argumen teks negosiasi akan diatasi dengan melaksanakan penyusunan dialog film pendek. Dalam kaitan itu, langkah-langkah umum yang akan dilakukan adalah: (1) perencanaan, yang meliputi menyiapkan rencana pembelajaran teks negosiasi dengan dialog film pendek dan rencana pengambilan data saat pembelajaran, menyiapkan instrumen atau lembar observasi untuk observer dan peneliti, serta menyiapkan indikator keberhasilan dan instrumen tes atau alat evaluasi, (2) pelaksanaan tindakan, yakni melaksanakan kegiatan pembelajaran dengan kegiatan pokok membuat dialog film pendek tentang negosiasi disertai argumen, dengan langkah: guru mengajukan alternatif pembuatan dialog film pendek sebagai media mengembangkan argumen, siswa berdiskusi dengan kelompok untuk merancang dialog dan persiapan pembuatan film termasuk fasilitas pendukung dan langkah-langkah pembuatan film negosiasi dengan perhatian pada aspek argumen, siswa merancang jadwal pembuatan film secara berkelompok, secara berkelompok siswa membuat film negosiasi dengan perhatian utama pada penyampaian argumen-argumen dalam negosiasi, guru memonitor pelaksanaan pembuatan film negosiasi, siswa mempresentasikan fim negosiasi yang dibuat, siswa mengamati dan mendiskusikan film yang dibuat terutama pada aspek dialog yang mengandung argumen, siswa mengembangkan secara tertulis argument yang masih lemah berdasarkan hasil pengamatan terhadap para negosiator dalam film, (3) melakukan pengamatan atau observasi secara cermat dalam pembelajaran yang diikuti dengan evaluasi, peneliti dibantu observer melakukan observasi terhadap pelaksanaan kegiatan atau tindakan pembelajaran teks negosiasi dengan kegiatan membuat film pendek kemudian mencatat kelebihan dan kekurangan saat pelaksanaan pembelajaran atau pelaksanaan tindakan, (4) menganalisis kegiatan guru dan siswa serta hasil evaluasi sebagai bentuk refleksi, dan (5) mengulangi proses tersebut minimal dua siklus sampai terpenuhinya indikator-indikator pencapaian kompetensi.

Data penelitian ini terdiri atas data kualitatif dan data kuantitatif. Data kualitatif diperoleh dari aktivitas guru dan siswa pada saat berlangsungnya pembelajaran materi teks negosiasi. Data kualitatif yang dimaksud meliputi hasil observasi terhadap proses belajar mengajar setiap siklus termasuk kelebihan dan kelemahan pembelajaran teks negosiasi, rencana pelaksanaan pembelajaran pada setiap siklus, hasil atau catatan-catatan observasi pembelajaran yang dilakukan peneliti maupun observer. Data kuantitatif diperoleh dari hasil tes tertulis yang dilaksanakan pada akhir setiap siklus pembelajaran materi teks negosiasi. 
Data penelitian dikumpulkan dengan beberapa metode, yaitu metode observasi yang mengikuti pandangan Sanjaya (2013) dan Sugiono (2009) dengan menerapkan teknik catat seperti yang dikemukakan Mahsun (2007), metode tes sebagaimana yang dikemukakan Nurgiyantoro (2010), catatan lapangan (field notes) seperti yang dikemukakan Kunandar (2008), dan metode dokumenter (Margono, 2007). Analisis data kualitatif akan dilakukan dengan mendeskripsikan atau menguraikan proses pembelajaran teks negosiasi yaitu siswa menyusun dialog dan menggunakannya dalam film pendek sesuai dengan data hasil observasi. Uraian dilakukan baik berkaitan dengan proses, kelebihan maupun kelemahan pelaksanaan pembelajaran. Analisis data kuantitaif dilakukan dengan mencermati hasil tes kemampuan atau kompetensi siswa dalam mengembangkan argumen teks negosiasi. Indikasi adanya peningkatan ditandai dengan peningkatan persentase pada: (1) nilai ratarata setiap aspek pengembangan argumen, yaitu kesesuaian dengan topik, kelengkapan data/fakta, kelogisan, keruntutan, dan efektivitas kalimat (2) nilai rata-rata siswa secara klasikal, dan (3) jumlah siswa yang tuntas (ketuntasan belajar) secara klasikal. Rumus-rumus yang digunakan untuk mengetahui persentase peningkatan tersebut adalah sebagai berikut.

a. Rumus untuk mengetahui rata-rata setiap aspek penilaian

$$
\mathrm{Xn}=\frac{\text { As }}{\mathrm{Js}_{\mathrm{S}}(\mathrm{x})} \times 100
$$

Keterangan :

$\mathrm{Xn}=$ nilai rata-rata setiap aspek (klasikal)

As = jumlah nilai setiap aspek secara keseluruhan

$\mathrm{Js}(\mathrm{x})=$ jumlah ideal (jumlah siswa $\mathrm{x}$ nilai tertinggi setiap aspek)

b. Rumus untuk mengetahui nilai rata-rata siswa secara klasikal $\overline{\mathrm{x}}=\frac{\sum \mathrm{f}(\mathrm{x})}{\mathrm{n}}$

Keterangan:

$\overline{\mathrm{X}} \quad=$ nilai rata-rata siswa $/$ mean

$\sum \mathrm{f}(\mathrm{x})=$ jumlah nilai siswa

$\mathrm{n} \quad=$ jumlah siswa.

c. Rumus untuk mengetahui persentase jumlah siswa yang tuntas (ketuntasan belajar) secara klasikal

KK: $\frac{X}{A} x 100 \%$

Keterangan:

$\mathrm{KK}=$ Ketuntasan Klasikal

$\mathrm{X}=$ Jumlah siswa tuntas belajar

A $=$ Jumlah seluruh siswa.

Peneitian ini dikatakan berhasil jika aktivitas guru dan siswa dalam pembelajaran berkategori baik atau sebagaian besar terlaksana dan $80 \%$ siswa berhasil mencapai nilai Kriteria Ketuntasan Minimal (KKM) 78

\section{Hasil dan Pembahasan}

Pembelajaran materi teks negosiasi yang dilaksanakan pada prasiklus (sebelum penggunaan media film), serta siklus I dan siklus II (menggunakan dialog dalam film pendek) menunjukkan adanya perubahan berupa peningkatan hasil belajar, baik ratarata setiap aspek kemampuan mengembangkan argumen teks negosiasi, nilai rata-rata secara klasikal, maupun persentase ketuntasan klasikal. Hal tersebut dapat dilihat pada tabel 1, 2, dan 3 berikut.

Tabel 1. Nilai Rata-Rata Setiap Aspek Kemampuan Mengembangkan Argumen Teks Negosiasi

\begin{tabular}{|c|c|c|c|c|}
\hline \multirow[b]{2}{*}{ No } & \multirow{2}{*}{$\begin{array}{l}\text { Aspek yang } \\
\text { dinilai }\end{array}$} & \multicolumn{2}{|c|}{ Rata-Rata Skor } & \multirow[b]{2}{*}{$\begin{array}{l}\text { Siklus } \\
\text { II }\end{array}$} \\
\hline & & Prasiklus & $\begin{array}{l}\text { Siklus } \\
\text { I }\end{array}$ & \\
\hline 1. & $\begin{array}{l}\text { Kesesuaian } \\
\text { dengan } \\
\text { Topik }\end{array}$ & 80,95 & 86,67 & 88,57 \\
\hline 2. & $\begin{array}{l}\text { Kelengkapan } \\
\text { Data/Fakta }\end{array}$ & 68,57 & 74,29 & 77,14 \\
\hline
\end{tabular}




\begin{tabular}{lllll}
\hline 3. & Kelogisan & 80,00 & 81,90 & 83,81 \\
4. & Keruntutan & 76,19 & 80,00 & 82,86 \\
5. & Keefektifan & 69,52 & 71,43 & 76,19 \\
& Kalimat & & & \\
\hline
\end{tabular}

Tabel 2. Peningkatan Nilai Rata-Rata Klasikal

\begin{tabular}{llll}
\hline \multirow{2}{*}{ No. } & \multicolumn{3}{l}{ Nilai Rata-Rata secara Klasikal } \\
\cline { 2 - 4 } & Prasiklus & Siklus I & Siklus II \\
\hline \multirow{2}{*}{1} & 75,05 & 78,86 & 81,71 \\
\hline
\end{tabular}

Tabel 3. Peningkatan Presentase Ketuntasan Belajar Klasikal

\begin{tabular}{llll}
\hline \multirow{2}{*}{ No. } & \multicolumn{4}{l}{ Nilai Rata-Rata secara Klasikal } \\
\cline { 2 - 4 } & Prasiklus & Siklus I & Siklus II \\
\hline \multirow{2}{*}{1} & $57,14 \%$ & $74,29 \%$ & $88,57 \%$ \\
\hline
\end{tabular}

Pada bagian pendahuluan telah dikemukakan bahwa dalam pembelajaran materi teks negosiasi di kelas X Mipa-2 tahun pelajaran 2020/2021 ditemui beberapa persoalan yang berkaitan dengan kemampuan siswa memenuhi kriteria yang ditetapkan, khususnya dalam hal kemampuan mengembangkan argumen. Persoalan tersebut berpengaruh terhadap pencapaian kompetensi siswa. Pengaruh yang dimaksud dapat dilihat dari data pembelajaran awal atau prasiklus. Pada tahap ini hanya 20 dari 35 siswa $(57,14 \%)$ yang mampu memenuhi batas ketuntasan 78 .

Peneliti melakukan diskusi dengan teman sejawat yaitu guru-guru Bahasa Indonesia SMAN 1 Mataram guna mendapatkan bahan dan data untuk mendukung perencanaan. Selanjutnya dilaksanakan kegiatan belajar mengajar dengan metode tanya jawab dan diskusi kelompok yang diakhiri dengan tes. Dalam pembelajaran itu dilakukan pengamatan dan wawancara dengan siswa untuk mendapatkan gambaran tentang kemampuan menyusun teks negosiasi dan kendala-kendala yang mereka alami. Berdasarkan hasil pengamatan dan wawancara tersebut diketahui beberapa kelemahan dan hambatan siswa dalam menyusun teks negosiasi, khususnya dalam pengembangan argumen.

Perbaikan dilakukan dengan mengubah pembelajaran yaitu dengan menugaskan siswa secara berkelompok menyusun dialog berisi argumen negosiasi dan mendialogkannya dalam film pendek. Film pendek tersebut berdurasi 5-15 menit (sesuai pendapat Trianton, 2013, yang menetapkan durasi film pendek paling lama 30 menit). Topik film pendek ditentukan sendiri oleh siswa bersama kelompoknya. Hasil implementasi tindakan tersebut dapat dilihat dalam pembahasan berikut.

\section{Siklus I}

Pada siklus I dilakukan: (1) penentuan strategi pembelajaran yang tepat untuk mengatasi kelemahan yang ditemukan pada prasiklus yaitu dengan menugaskan siswa membuat dialog film pendek dengan fokus pada pengembangan argumen dan dialog tersebut nantinya akan diterapkan dalam membuat film pendek, (2) membuat rencana pelaksanaan pembelajaran yang menerapkan pelaksanaan pembelajaran teks negosiasi melalui dialog film pendek, (3) membuat lembar observasi tindakan guru, (4) membuat lembar observasi kegiatan siswa, dan (5) menyusun instrumen penilaian bak penilaian proses maupun penilaian hasil.

Berdasarkan rencana pemecahan masalah telah direncanakan dan tersusun dalam rencana pelaksanaan pembelajaran (RPP). Pelaksanaan tindakan siklus I berlangsung sebanyak empat kali pertemuan. Kegiatan inti yang dilaksanakan dalam pelaksanaan pembelajaran pertemuan I adalah: (1) guru meminta siswa membentuk tujuh kelompok yang masing-masing terdiri dari lima orang anggota dan siswa diberi kebebasan dalam memilih anggota kelompok untuk memudahkan mereka dalam berkoordinasi dan bekerja, (2) guru menjelaskan kegiatan yang akan dilakukan yaitu rencana membuat dialog film pendek yang berkaitan dengan proses negosiasi, (3) menentukan topic, alur cerita, dan pelaku negosiasi, (4) siswa menyusun naskah dialog negosiasi dengan lebih fokus pada pengembangan argumen, (3) guru melakukan 
pembimbingan dan pendampingan saat siswa menyusun dialog (4) guru dan siswa merancang pembuatan film negosiasi yang meliputi : penentuan waktu dan lokasi pembuatan film negosiasi, penentuan tugas masing-masing anggota kelompok dalam pembuatan film negosiasi, dan penentuan jadwal syuting dan editing, (4) guru menugasi siswa untuk membuat film negosiasi sesuai dengan rancangan kelompok dengan lokasi dialog film pendek ditentukan oleh masingmasing kelompok, (5) guru dan siswa menyepakati jadwal presentasi film untuk masing-masing kelompok.

Kegiatan yang dilaksanakan dalam pelaksanaan pembelajaran pertemuan II adalah: (1) guru mengecek perkembangan tugas siswa membuat dialog film pendek negosiasi yang dilakukan masing-masing kelompok, (2) setiap kelompok melaporkan perkembangan dialog film pendek termasuk kendala yang mungkin dihadapi, (3) guru memberikan arahan dan penguatan terutama pada aspek argumen yang disampaikan siswa dalam dialog film pendek, (4) guru menugaskan siswa membuat film pendek dengan menerapkan dialog yang sudah disusun dalam kelompok, (5) guru mengingatkan kelompok untuk mempersiapkan diri melakukan presentasi pada pertemuan berikutnya dan menyepakati pola presentasi yang akan dilakukan. Pada pertemuan III dan IV secara berkelompok siswa mempresentasikan film pendek yang telah dibuat, mencermati argumen-argumen yang disampaikan dalam film negosiasi kelompok lain, mendiskusikan dalam kelompoknya kelebihan dan kekurangan argumen setiap negosiator dalam film pendek yang disaksikan, dan mengembangkan argumen negosiator tertentu dalam film negosiasi yang dicermati, yaitu argumenargumen yang dianggap masih lemah dengan menambahkan alasan-alasan pendukung.

Refleksi perencanaan siklus I menunjukkan bahwa perencanaan waktu presentasi hasil film perlu diperbaiki.
Kelemahan perencanaan waktu ini menyebabkan beberapa kelompok kekurangan waktu untuk melakukan presentasi, padahal presentasi juga akan memengaruhi aktivitas selanjutnya yaitu siswa mencermati argumen negosiator dalam film pendek yang dibuat kelompok lain kemudian melengkapi alasan yang menguatkan argumen jika argumen tersebut masih lemah. Refleksi pelaksanaan menunjukkan bahwa secara umum kegiatan yang direncanakan telah dilaksanakan oleh guru namun belum optimal terutama pada saat siswa mendiskusikan alasan-alasan yang menguatkan argumen. Hal ini disebabkan siswa ternyata lebih tertarik pada pembuatan film pendek khususnya alur film yang akan mereka buat. Siswa mengutamakan aspek keseruan dan ketegangan dalam film pendek. Ada beberapa kelompok yang kurang memperhatikan isi dialog yang menjadi hal pokok. Kelemahan lainnya adalah guru belum melaksanakan observasi di luar kelas, yaitu saat siswa melakukan dialog film pendek yang berlokasi di luar lingkungan sekolah. Dalam pembuatan film negosiasi terdapat tiga kelompok yang membuat film dengan durasi yang melebihi waktu 15 menit yang ditentukan. Ada kelompok yang membuat film dengan durasi lebih dari 30 menit. Hal ini menyebabkan waktu untuk presentasi menjadi lebih panjang (karena harus menyaksikan tayangan film dalam waktu yang lebih lama) dan berpengaruh pada kesempatan presentasi untuk kelompok lain.

Pada bagian akhir siklus I dilakukan tes tertulis untuk mengetahui kemampuan siswa mengembangkan argument bernegosiasi. Walapun hasil tes menunjukkan angka yang lebih baik daripada saat prasiklus, pelaksanaan tindakan pada siklus I belum dapat dikatakan berhasil karena belum mencapai tingkat keberhasilan ketuntasan klasikal 80\% yaitu hanya $74,29 \%$.

\section{Siklus II}

Berdasarkan refleksi pembelajaran pada siklus I, dibuat perencanaan tindakan siklus II, 
yaitu: (1) mendesain kembali rencana pelaksanaan pembelajaran dan melaksanakannya terutama pengaturan waktu untuk pembimbingan dan pendampingan saat diksusi kelompok menyusun dialog agar lebih efektif, (2) mengubah jumlah dan komposisi anggota kelompok, yakni kelompok semula berjumlah 7 diubah menjadi 5 kelompak dengan alasan efektivitas waktu diskusi, penyajian, dan pendampingan diskusi di kelas. Dari aspek komposisi anggota kelompok, siswa yang belum tuntas dikelompokkan dengan siswa yang sudah tuntas dengan nilai tinggi dan diberikan tugas membuat dialog dan film negosiasi, (3) mengingatkan siswa untuk lebih fokus membahas alasan-alasan yang menguatkan argumen dalam dialog film pendek yang akan dbuat, (4) merencanakan keterlibatan secara lebih intens siswa yang sudah tuntas dalam membantu siswa yang belum tuntas, (5) memprogramkan kegiatan observasi oleh peneliti di luar kelas, (6) menegaskan durasi film agar tidak melebihi batas waktu yang disepakati, dan (7) mengatur waktu presentasi yang lebih proporsional.

Pelaksanaan tindakan siklus II berlangsung sebanyak empat kali pertemuan. Pada pertemuan I dilakukan perubahan jumlah dan anggota kelompok. Anggota kelompok ditentukan oleh guru dengan memperhatikan jumlah siswa yang tuntas dan tidak tuntas. Guru melibatkan beberapa siswa yang mendapatkan nilai tertinggi untuk aktif dalam kelompok. Guru juga lebih intesif mendampingi dan membiming siswa untuk lebih fokus pada penyusunan dialog yang mengandung alasan yang memperkuat argumen negosiasi. Pengecekan tugas siwa dilakukan pada pertemuan II. Pada pertemuan II ini guru juga menugasi siswa untuk memperbaiki film negosiasi sesuai dengan rancangan kelompok dengan menekankan bahwa durasi film pendek tidak boleh lebih dari 15 menit. Pada pertemuan III dan IV secara berkelompok siswa mempresentasikan film pendek yang telah dibuat, mencermati argumen-argumen yang disampaikan dalam film negosiasi kelompok lain, mendiskusikan dalam kelompoknya kelebihan dan kekurangan argumen setiap negosiator dalam film pendek yang disaksikan, dan mengembangkan argumen negosiator tertentu dalam film negosiasi yang dicermati, yaitu argumen-argumen yang dianggap masih lemah dengan menambahkan alasan-alasan pendukung.

Hasil observasi dan refleksi pembelajaran siklus II menunjukkan bahwa perencanaan kegiatan telah dilakukan dengan baik. Kelemahan perencanaan pada siklus I yang berkaitan dengan pembimbingan dan observasi oleh guru saat siswa melakukan aktivitas pembuatan film, telah diperbaiki. Demikian pula dengan telah dilakukannya perbaikan perencanaan dan pelaksanaan waktu presentasi film pendek untuk masingmasing kelompok. Dalam pelaksanaan pembelajaran, siswa sudah lebih fokus pada penyusunan argumen saat menyusun dialog film pendek. Mereka memahami bahwa tujuan utama pembelajaran adalah untuk menguatkan argumen dalam negosiasi tanpa mengabaikan alur cerita film pendek. Saat presentasi berupa penayangan film pendek mereka di kelas, argumen yang ada dalam film pendek negosiasi dapat diterima dan logis. Setelah dilaksanakan tes akhir, hasil belajar kemampuan mengembangkan argumen dalam teks negosiasi dengan dialog film pendek mencapai tingkat keberhasilan lebih dari $80 \%$. Sampai dengan siklus II, hasil ketuntasan yang dicapai adalah $88,57 \%$.

\section{Kesimpulan}

Berdasarkan uraian pada bagian pembahasan dapat disimpulkan bahwa terdapat peningkatan kemampuan siswa kelas $X$ Mipa-2 SMAN 1 Mataram tahun pelajaran 2020/2021 dalam mengembangkan argumen teks negosiasi setelah mengikuti pembelajaran dengan proses menyusun dialog dan membuat film pendek. Hal terebut dibuktikan dengan 
adanya peningkatan nilai rata-rata siswa secara klasikal yaitu dari 75,05 pada prasiklus menjadi 78,86 (siklus I), dan 81,71 (siklus II), dan peningkatan ketuntasan belajar secara klasikal yaitu dari $57,14 \%$ pada prasiklus menjadi $74,29 \%$ (siklus I), dan 88,57\% (siklus II).

\section{Saran}

Dua aspek kemampuan mengembangkan argumen teks negosiasi yang masih belum mencapai angka 80 dalam penelitian ini adalah kelengkapan data/fakta serta keefektifan kalimat. Oleh karena itu diharapkan adanya penelitian lebih lanjut berkaitan dengan peningkatan kemampuan siswa pada dua aspek tersebut. Disarankan pula agar penelitian yang berkaitan dengan peningkatan kemampuan membuat teks negosiasi dan mempraktikkan negosiasi terus dilakukan sehingga pembelajaran akan lebih kaya dengan model dan metode dalam rangka mencapai kompetensi yang diharapkan.

\section{Daftar Pustaka}

Arsyad, A. (2016). Media Pembelajaran. Jakarta: Raja Grafindo Persada.

Guntur, A. (2010). Strategi Negosiasi. Jakarta: Stekpi.

Jefrilianto, Zafri, dan Ofianto. (2019). Pengaruh Penggunaan Media Film dalam Meningkatkan Hasil Belajar Siswa SMA Negeri 1 Ulakan Tapakis. Ranah Research: Journal of Multidicsiplinary Research and Development, 1(2). 332 - 342.

Kunandar. (2008). Langkah Mudah Penelitian Tindakan Kelas sebagai Pengembangan Profesi Guru. Jakarta: Rajawali Pers.

Maharani, I., Fridani, F., \& Akbar, Z. (2019). Penggunaan Media Film Bertema Pendidikan dalam Layanan Informasi Bimbingan Klasikal. Faktor: Jurnal Ilmiah Pendidikan. 6(2). 13-146.
Mahsun. (2007). Metode Penelitian Bahasa: Tahapan Strategi, Metode, dan Tekniknya. Jakarta: Rajawali Pers.

Margono, S. (2007). Metode Penelitian Pendidikan. Jakarta: Rineka Cipta.

Musfiqon, H.M. (2012). Pengembangan Media dan Sumber Pembelajaran. Jakarta: Prestasi Pustakaraya.

Nurgiyantoro, B. (2010). Penilaian Pembelajaran Bahasa Berbasis Kompetensi. Yogyakarta: BPFE.

Sanjaya, W. (2013). Penelitian Tindakan Kelas. Jakarta: Kencana.

Sugiyono. (2009). Metode Penelitian Pendidikan: Pendekatan Kuantitatif, Kualitatif, dan $R \mathcal{E D}$. Bandung: Alfabeta.

Trianton, T. (2013). Film sebagai Media Belajar. Yogjakarta: Graha Ilmu.

Wardhani, I.G.A.K. (2007). Penelitian Tindakan Kelas. Jakarta: Universitas Terbuka.

Weston, A. (2007). Kaidah Berargumentasi. Yogyakarta: Pustaka Pelajar. 